\title{
ETOS KERJA DALAM PERSPEKTIF ISLAM \\ Saifullah
}

\section{Pendahuluan}

Agama Islam adalah agama serba lengkap, yang di dalamnya mengatur seluruh aspek kehidupan manusia baik kehidupan spiritual maupun kehidupan material termasuk di dalamnya mengatur masalah Etos kerja. Secara implisit banyak ayat al Qur'an yang menganjurkan umatnya untuk bekerja keras, diantaranya dalam Quran surat al Insirah: 7-8, yang artinya ”Apabila kamu telah selesai (dari satu urusan), maka kerjakan dengan sungguh-sungguh (urusa) yang lain". Juga dijelaskan dalam hadis Rosul yang artinya: "Berusahalah untuk urusan duniamu seolah-olah engkau akan hidup selamanya”.

Al Qur'an dan Hadis tersebut menganjurkan kepada manusia, khususnya umat Islam agar memacu diri untuk bekerja keras dan berusaha semaksimal mungkin, dalam arti seorang muslim harus memiliki etos kerja tinggi sehingga dapat meraih sukses dan berhasil dalam menempuh kehidupan dunianya di samping kehidupan akheratnya.

Namun dalam realitas kehidupan, masih banyak bangsa Indonesia khususnya umat Islam yang bersikap malas, tidak disiplin, tidak mau kerja keras, dan bekerja seenaknya. Hal ini didukung kenyataan berupa kebiasaan yang disebut dengan "jam karet", maksudnya kalau mengerjakan sesuatu sering tidak tepat waktu atau sering terlambat dan sebagainya. Ini berarti bahwa bangsa Indonesia yang mayoritas penduduknya umat Islam masih memiliki etos kerja rendah.

Ada asumsi yang mengatakan bahwa bangsa Indonesia memiliki etos kerja rendah, disebabkan karena banyak umat Islam yang menempuh kehidupan tasawuf. Hal ini dapat dibenarkan karena di dalam tasawuf ada ajaran yang melemahkan etos kerja seseorang. Misalnya ajaran tasawuf tentang 'uzlah, zuhd, tawakkal, qana'ah, faqr, dan amalan lainnya, ditambah lagi dengan kebiasaan membaca dhikr, wirid dan do'a yang amat menyita waktu, sehingga mengurangi kesempatan untuk berkarya guna memenuhi kebutuhan material (duniawi). 
Bagaimana sebenarnya ajaran Islam tentang Etos kerja dan bagaimana umatnya seharusnya bekerja? Melalui makalah ini, penulis mencoba memaparkan tentang Etos kerja dalam perspektif Islam dengan pendekatan teoritis maupun praktis, dengan harapan semoga dapat bermanfaat bagi umat Islam sekaligus dapat memotivasi diri untuk bekerja keras. Dan dapat menambah khazanah keilmuan semakin mendalam.

\section{Definisi Etos Kerja}

Perbincangan tentang etos kerja, di kalangan ilmuwan, cendikiawan, birokrat dan politisi bukanlah sesuatu yang baru. Hal itu bukan berarti para pakar telah memberikan satu definisi yang seragam tentang pengertian etos kerja.

Menurut. Nurcholis Majid (1995), etos artinya watak, karakter, sikap, kebiasaan dan kepercayaan yang bersifat khusus tentang seseorang induvidu atau sekelompok manusia. Sedangkan Cliffoot Greertz (1997), etos adalah sikap mendasar manusia terhadap diri dan dunia yang dipancarkan dalam hidup, dan etos erat kaitannya dengan aspek moral maupun etika yang dihasilkan oleh budaya.

Pandji Anoraga (1992), kerja adalah bagian yang paling esensial dari kehidupan manusia, ia akan memberikan status dari masyarakat yang ada di lingkungannya, sehingga dapat memberikan makna dari kehidupan manusia yang bersangkutan. Sedangkan El-Qussy(1974), seorang pakar Ilmu Jiwa kebangsaan Mesir, mengatakan bahwa kerja adalah perbuatan yang berhubungan dengan mental, yang mempunyai ciri kepentingan, yaitu untuk mencapai maksud atau mewujudkan tujuan tertentu.

Dari sejumlah definisi tersebut, dapatlah dipahami bahwa etos kerja, Pertama adalah sikap seseorang atau suatu bangsa yang sangat mendasar tentang kerja, yang merupakan cerminan dari pandangan hidup yang berorientasi dari nilai-nilai ketuhanan (ilahiyah). Kedua, Etos kerja adalah pancaran dari sikap hidup manusia yang mendasar terhadap kerja dan kerja yang dimaksud adalah kerja bermotif yang terikat dengan penghasilan atau upaya memperoleh hasil, baik yang bersifat material manupun non material (spiritual). 


\section{Tujuan dan Motivasi Kerja}

Yang dimaksud tujuan kerja adalah target yang ingin dicapai oleh seseorang dalam bekerja. Tujuan dalam kerja sebenarnya tidak lepas dari latar belakang yang menjadi motivasi seseorang dalam bekerja. Hal penting yang senantiasa melatar belakangi seseorang dalam mencapai tujuan dalam bekerja adalah faktor kebutuhan. Pada dasarnya kebutuhan manusia terdiri atas dua macam kebutuhan pokok, yaitu kebutuhan material dan kebutuhan spiritual. Kebutuahan spiritual sangat penting peranannya dalam memotivasi seseorang untuk melakukan pekerjaan guna memenuhi kebutuhan material.

Dalam kaitannya dengan tujuan dan motivasi kerja, Hadari Nawawi (2001) mengemukakan bahwa, ada dua macam motivasi yang mendorong manusia ke arah tujuan kerjanya, yaitu: motivasi intristik dan motivasi ekstrintik. Motivasi intristik adalah motivasi yang menyertai seseorang bekerja dengan dedikasi tinggi karena merasa memperoleh kesempatan untuk tujuan dapat mengaktualisasikan diri dengan maksimal, sedangkan motivasi ekstrintik adalah motivasi yang menyertai seseorang bekerja dengan cukup dedikasi karena tujuan ingin memperoleh uang atau gaji tinggi.

Dari paparan tersebut patutlah disepakati bahwa bekerja yang benar mempunyai tujuan ganda yaitu ukhrawi yaitu ingin mendapat pahala mencari keridlaan Allah Swt, karena bernilai ibadah dan duniawi dalam arti ingin mendapat imbalan materi materi berupa uang atau gaji, guna mencukupi kebutuhan hidup keluarganya. Namun perlu diperhatikan bahwa tujuan bersifat material berarti imbalan upah, gaji yang setimpal, terkadang disalah artikan dengan memperoleh imbalan sebanyak-banyaknya yang ujung-ujungnya hanya dipakai untuk bersenang-senang (hedonisme) serta pamer pada sesama dalam kedudukan sosial, yang pada akhirnya menghalalkan bergai cara, seperti menipu, korupsi dan lain-lain.

Tentang motivasi kerja, Anwar Prabu Mangkunegara (2007) memberikan definisi motivasi kerja dengan mengutip pendapat Ernest J.McCormick sebagai berikut: Work motivation is defined as conditions which influence the arousal, direction, and maintenance of behaviors relevant in work 
settings (Motivasi kerja adalah kondisi yang berpengaruh membangkitkan, mengarahkan, dan memelihara perilaku yang berhubungan dengan lingkungan kerja).

David C. Mc Clelland berkomentar, ada tiga motivasi yang dimiliki oleh seseorang dalam bekerja, yaitu: Pertama, motivasi yang didasarkan atas ketakutan (fear motivation). Dia melakukan sesuatu karena takut jika sesuatu yang buruk akan terjadi, misalnya orang patuh pada bos karena takut dipecat dari pekerjaannya. Kedua, motivasi karena ingin mencapai sesuatu (achievement motivation). Seseorang mau melakukan sesuatu karena ingin mencapai suatu prestasi tertentu. Ketiga adalah motivasi yang didorong oleh kekuatan dari dalam atau kekuatan batin (inner motivation), yaitu kekuatan yang mendasari tujuan hidupnya. (Prabu Mangkunegara, 2007).

Dengan tidak melebihkan dan melemahkan berbagai teori dan pendapat di atas, penulis menyimpulkan bahwa motivasi kerja yang mampu membentuk seseorang beretos kerja tinggi adalah kebutuhan untuk berprestasi yang didorong oleh kekuatan spiritual sehingga mampu melaksanakan kewajiban pekerjaannya dengan amanah penuh tanggung jawab.

Di samping tujuan dan motivasi, ada juga beberapa unsur yang turut menentukan tinggi rendahnya etos kerja seseorang, sebagaimana dikemukakan Hadari Nawawi bahwa, setidaknya ada lima unsur-unsur etos kerja, yang apabila lima unsur tersebut baik maka baiklah etos kerja seseorang dan apabila lima unsur tersebut jelak maka jeleklah etos kerja seseorang. Lima unsur etos kerja tersebut adalah motivasi kerja, tujuan kerja, pola kerja, semangat kerja dan tekat kerja. Lima unsur inilah yang banyak digunakan oleh para peneliti untuk mengukur tinggi rendah etos kerja seseorang.

\section{Faktor-faktor yang Mempengaruhi Etos Kerja}

Tinggi rendahnya kualitas sumber daya manusia tidak lepas dari faktorfaktor yang mempengaruhinya, tidak terkecuali masalah etos kerja. Ada beberapa faktor yang dapat mempengaruhi tinggi rendahnya etos kerja seseorang, namun 
secara umum dapat diklasifikasikan menjadi 2 (dua) macam yaitu faktor internal dan faktor eksternal.

\section{a) Faktor Internal}

Yang dimaksud faktor internal adalah faktor yang berasal dari suasana batin atau semangat hidup (inner life). Faktor ini dapat menggerakan atau membangkitkan seseorang bahkan dapat menjadi mesin pendorong yang amat dasyat. Dan biasanya faktor ini berasal dari ajaran agama yang diyakininya.

Dalam realitasnya, salah satu faktor yang mendorong tergeraknya hati melakukan sesuatu adalah faktor agama (ideologi). Jiwa ibarat gelas, semua doktrin baik doktrin teologi atau lainnya merupakan isi gelas tersebut. Isi gelas sangat tergantung dari warna apa yang masuk kedalam gelas tersebut. Demikian juga etos kerja seseorang atau kelompok masyarakat sangat ditentukan oleh doktrin yang masuk dalam jiwanya. Jika isi doktrin melemahkan etos kerja, maka prestasi kerja yang dicapainya akan rendah, jika isi doktrin mendorong tumbuhnya etos kerja maka prestasi kerja yang dicapainya akan tinggi.

Sedikitnya ada tiga doktrin keagamaan atau doktrin teologi yang mempengaruhi etos kerja seseorang, di antaranya sebagai berikut:

1. Faham Jabariyah (fatalisme). Faham ini berpendapat bahwa manusia bukanlah pencipta perbuatannya sendiri, dan perbuatan itu sama sekali tidak dapat diidentikkan (dinisbahkan) kepadanya. Intinya pendapat ini menafikan kemampuan, kesanggupan dan daya bagi manusia dan semua perbuatan manusia adalah keterpaksaan belaka yang itu semuanya merupakan ciptaan Tuhan semata.

2. Faham Qadariyah (free will). Faham ini berpendapat bahwa semua perbutan manusia adalah atas kehendaknnya sendiri. Manusia bebas menentukan perbuatannya sendiri tanpa ada campur tangan (intervensi) dari kehendak Allah. Semua urusan saat ini (sekarang), ditentukan oleh Manusia sendiri, tidak ada ketentuan Allah. 
3. Faham Sunni (ahli sunnah wal Jama'ah). Faham ini dikenal sebagai aliran jalan tengah dari dua faham sebelumnya yang saling bertolak belakang. Aliran ini mempunyai pemahaman bahwa semua perbuatan manusia ada kaitannya dengan ketentuan Allah, tetapi Allah memberikan manusia potensi untuk melakukan usaha atau ihtiar. Dan jika usahanya sungguhsungguh maka manusia dapat merubah nasibnya sendiri dengan izin Allah swt. (Abu Zahrah, 1996)

Sementara Max Weber dalam "The Protestant Ethic and The Spirit of Capitalism", berpendapat bahwa orang-orang Protestan (sekte Calvinis) lebih sukses dalam kehidupan ekonominya, karena dari fakta sosiologis yang ditemukan di Jerman. Dalam ajaran Protestan (sekte Calvinis) dinyatakan bahwa, bekerja keras bukan hanya sekedar upaya memenuhi keperluan hidup, tetapi lebih dari itu, merupakan tugas suci agama guna memperoleh keselamatan hidup di akherat.

Robert N. Bellah, juga mengadakan penelitian terhadap masyarakat Jepang dan hasilnya menunjukkan bahwa, kemajuan yang diraih oleh masyarakat Jepang sangat berkaitan erat dengan ajaran agama yang di anutnya yaitu: Shinto, Budha dan Tao, terutama di era Tokugawa. Dari realitas tersebut dapatlah disimpulkan bahwa ternyata agama dapat memberikan pengaruh yang positif, bukan hanya terhadap aktivitas ekonomi, melainkan juga berpengaruh terhadap semua aspek kehidupan, seperti perkembangan sains, pendidikan, politik, hukum dan lainya.( Robert N. Bellah, 2000)

Dari tesis weber dan Bellah tersebut dapatlah disimpulkan bahwa faktor internal yang yang dapat mempengaruhi tinggi rendahnya etos kerja seseorang adalah faktor ajaran agama atau keyakinan yang dianutnya. Doktrin agama apat memberikan pengaruh positif terhadap etos kerja seseorang, manakala dapat memotivasi umatnya untuk meraih prestasi kerja yang tinggi, dan sebaliknya doktrin agama dapat memberikan pengaruh negatif (melemahkan etos kerja), manakala tidak mampu mendorong umatnya untuk meningkatkan etos kerjanya. 


\section{b. Faktor Eksternal}

Maksud faktor eksternal adalah pengaruh yang datangnya dari luar diri manusia, yakni faktor lingkungan, baik lingkungan rumah tangga maupun lingkungan kerja. Jelasnya masalah keluarga, anak, istri, teman, tetangga, dan masalah lingkungan kerja yang tidak kondusif dapat memberikan pengaruh baik atau buruh terhadap etos kerja seseorang.

Pandji Anoraga (1992), menjelaskan bahwa ada beberapa faktor eksternal yang dapat memberikan pengaruh terhadap tinggi rendahnya etos kerja seseorang, di antaranya:

1. Faktor utama yaitu keamanan kerja (Job Security). Para pekerja yakin bahwa mereka akan memiliki etos kerja tinggi, apabila pekerjaannya merupakan pekerjaan yang aman dan tetap, artinya tidak mudah diganti atau diberhentikan.

2. Faktor kedua kesempatan untuk mendapatkan kemajuan (opportunities for advancement). Manusia hidup ingin mendapatkan penghargaan, perhatian terhadap diri dan prestasinya. Karena itu faktor kenaikan pangkat, gaji, tingkat dan lainnya harus diperhatikan oleh atasan.

3. Faktor ketiga adalah kondisi kerja yang menyenangkan (suasana kondusif). Suasana kerja yang harmonis, tidak tegang, tidak suram, tidak gaduh merupakan syarat bagi meningkatnya etos kerja seseorang.

4. Faktor keempat adalah rekan kerja yang baik (good workong companion). Hubungan sosial atau interaksi sosial antar karyawan merupakan faktor yang cukup penting dalam menumbuhkan gairah kerja dan etos kerja.

5. Faktor kelima adalah adanya kompensasi, gaji atau imbalan. Faktor ini walaupun pada umumnya tidak menempati urutan paling atas, tetapi hal ini termasuk dapat mempengaruhi ketenangan, dan semangat kerja.

Dalam kaitannya dengan faktor internal dan eksternal tersebut, Toto Tasmara (1995) berpendapat bahwa banyak nilai-nilai yang terlahir dari keyakinan, sistem pendidikan, budaya, dan adat istiadat yang bertentangan dengan nilai-nilai Islam, jika tidak segera diluruskan dapat melemahkan etos kerja. Nilai-nilai tersebut di antaranya adalah: 1). Khurafat dan tahayul 2). 
Pandangan hidup dunia yang keliru 3). Sikap kerja asal-asalan atau kerja seenaknya 4). Sikap fatalistis 5). Adanya persepsi yang salah tentang kerja 6). Kepercayaan terhadap jimat atau maskot.

Harus yakin bahwa semangat juang yang mempengaruhi etos kerja muslim tidak datang dari benda-benda keramat, tetapi dari energi dorong yang kuat dari keyakinan terhadap Allah Swt. Kualitas keyakinan kepada Allah (tauhidullah) inilah, yang menentukan atau mempengaruhi etos kerja seseorang, jika keyakinannya tipis atau lemah maka etos kerjanya rendah dan sebaliknya apabila keyakinannya kuat maka etos kerjanya akan tinggi.

\section{Etos Kerja dalam Perspektif Islam}

Agama Islam adalah agama serba lengkap, yang di dalamnya mengatur seluruh aspek kehidupan manusia baik kehidupan spiritual yang bersifat ukhrawi maupun kehidupan material yang bersifat duniawi termasuk di dalamnya mengatur masalah Etos kerja.

Secara implisit banyak ayat al Qur'an yang menganjurkan umatnya untuk bekerja keras, dalam arti umat Islam harus memiliki etos kerja tinggi, diantaranya dalam Quran surat al Insirah: 7-8, yang artinya "Apabila kamu telah selesai (dari satu urusan), maka kerjakan dengan sungguh-sungguh (urusan) yang lain”. Ayat ini menganjurkan kepada manusia, khususnya umat Islam agar memacu diri untuk bekerja keras dan berusaha semaksimal mungkin, dalam arti seorang muslim harus memiliki etos kerja tinggi sehingga dapat meraih sukses dan berhasil dalam menempuh kehidupan dunianya di samping kehidupan akheratnya.

\section{a. Keseimbangan antara Kerja dan Ibadah}

Yusuf Qardhawi (1996:12) menjelaskan, bahwa Agama Islam memiliki beberapa karakteristik, salah satu di antaranya adalah wasatiyah atau dengan istilah lain tawazun, yaitu sikap hidup pertengahan atau sikap seimbang antara kehidupan material dan spiritual. Ini artinya sebagai seorang Muslim harus dapat menyeimbangkan antara dua kutub kehidupan yaitu kehidupan material yang bersifat duniawi dan kehidupan spiritual yang bersifat ukhrawi. 
Nilai moderat inilah yang mengantarkan dan mengisyartkan umat Islam menempatkan diri sebagai umat pertengahan, kelompok moderat dibanding dengan umat-umat lain yang cenderung berlebih-lebihan di antara salah satu aspek yang berlawanan. Misalnya ada umat yang cenderung kepada spiritual belaka sehingga mengabaikan aspek fisik material, yang cenderung hidup bertapa mengasingkan diri dari halayak ramai, pantang kawin, dan berpuasa sepanjang waktu. Tetapi sebaliknya terdapat pula golongan yang berwawasan keduniaan belaka dan menganggap akhirat tidak penting, ini penganut faham materialisme dan sekulerisme, mereka tidak mau tahu tentang Tuhan dan agama serta tidak percaya adanya hari pembalasan di hari kiamat. (Hamzah Ya'qub, 1992; 62)

'Aqidah, syari'ah Islam menolak keduanya dan mengambil jalan lurus, yaitu jalan moderat sesuai dengan satusnya sebagai ummah wasatiyah (ummat pertengahan), sebagaimana difirmankan Allah dalam al-Qur'an surat AlBaqarah: 143, yang artinya: Dan demikianlah kami telah menjadikan kamu (umat Islam), sebagai umat pertengahan, agar kamu menjadi saksi atas (perbuatan) manusia.

Ayat ini memberikan penjelasan bahwa umat Islam bukanlah ummat yang ekstrim dan radikal, yang condong pada salah satu aspek kehidupan saja, akan tetapi umat Islam adalah ummat yang berupaya berpegang teguh pada prinsip keseimbangan hidup, keselarasan hidup dan prinsip inilah yang mewarnai etos kerjanya, sehinga kerja-kerja ekonomi dan ibadahpun menjadi selaras dan seimbang, dalam arti masing-masing dikerjakan sesuai dengan jadwal waktunya.

Islam memiliki banyak kelebihan, yang dengannya dapat membedakan dengan agama lainnya. Di antara kelebihan Islam adalah adanya asas keseimbangan, wawasan keselarasan dan keserasian antara duniawi dan ukhrawi, antara material dan spiritual, antara lahir dan batin, antara kerja guna memenuhi kebutuhan keluarga dengan ibadah

Dalam ayat lain, Allah berfirman : Artinya : Dan carilah karunia yang Allah berikan kepadmu di negeri akherat, tetapi jangnlah kamu lupakah 
bagianmua di dunia.(Qs. Al Qashash:77). Melalui ayat tersebut Allah hendak memberikan informasi tentang pentingnya keharmonisan atau keseimbangan antara kerja-kerja ukhrawi tanpa melupakan kerja-kerja ekonomi guna memenuhi kebutuhan hidup duniawi.

Tentang pentingnya keseimbangan antara dua aspek kehidupan manusia (material dan spiritual) telah disinggung oleh Rasulullah Muhammad Saw melalui sabdanya: Berusahalah untuk urusan duniamu seolah-olah engkau akan hidup selamanya, dan berusahalah untuk urusan akhiratmu seolah-olah engkau akan mati besok pagi. (Al Hadis: Ibnu Asakir)

Hadis tersebut menganjurkan kepada manusia, khususnya umat Islam tentang pentingnya dua tempat kehidupan, yaitu, Pertama, tentang pentingnya kehidupan dunia. Jika manusia ingin meraih sukses dan berhasil dalam menempuh kehidupan dunianya, maka manusia harus memacu dirinya untuk bekerja keras dan berusaha semaksimal mungkin, dalam arti seorang muslim harus memiliki etos kerja tinggi. Kedua, tentang pentingnya kehidupan akherat. Jika manusia ingin meraih sukses dan berhasil dalam kehidupan akheratnya, maka manusia harus meningkatkan spiritualitasnya, mendekatkan diri kepada Allah Swt, sehingga akhirnya diperoleh ketenangan jiwa.

Untuk memenuhi kebutuhan hidup yang bersifat duniawi, seorang muslim dituntut berikhtiar semaksimal mungkin, baik secara lahir maupun batin. Ikhtiar lahir dilakukan dengan berusaha seoptimal mungkin sesuai dengan kemampuan yang dimiliki, dalam arti harus memiliki etos kerja atau semangat kerja tinggi, dan ikhtiar batin dilakukan dengan banyak berdhikir dan berdo'a memohon pertolongan hanya kepada Allah Swt. Bekerja keras yang dibarengi dengan berdzikir dan berdo'a inilah yang menjadi ciri khas etos kerja seorang muslim, jika hal ini terrealisasi dalam kehidupannya, maka dapat menghasilkan rizki yang halal dan diridlai Allah, yang pada akhirnya akan mendapatkan keberkahan dan keuntungan dunia akherat.

Setelah bekerja keras, berdzikir dan berdo'a, maka berhasil tidaknya diserahkan keputusan akhirnya kepada Allah Swt. Di sinilah posisi tawakkal atau berserah diri dan ridla dalam menerima keputusan Allah. Apabila 
keputusan Allah sesuai dengan usaha keras dan permohonan, berarti kesuksesan yang diraih (kaya), maka diharuskan untuk mensyukurinya, namun apabila ternyata keputusan Allah tidak sesuai dengan yang diharapkan, dalam arti gagal (miskin), maka harus bersabar dan tabah mengahadapinya.

Konsep ajaran Islam tersebut apabila dijadikan pegangan hidup setiap muslim, maka akan mendapatkan ketenangan hidup dalam menghadapi segala situasi dan kondisi apapun. Sukses tidak sombong dan gagalpun tidak akan berputus harapan, apalagi putus asa. Sikap Syukur apabila sukses dan sabar apabila gagal, akan menjadikan kita punya sikap qana'ah, yang pada gilirannya akan membawa ketenangan dan ketentraman dalam hidup. Dan inilah hakekat kebahagiaan hidup yang sebenarnya.

\section{b. Pentingnya Spiritualitas dalam Kerja}

Banyak faktor yang turut menentukan dalam suatu pekerjaan. Di antaranya adalah faktor spiritualitas (mental, jiwa), sehebat apapun peralatan canggih yang digunakan di jaman modern ini, jika pekerja-pekerja tidak memiliki mentalitas dan semangat kerja tinggi maka tujuan pekerjaan tidak akan dapat tercapai.

Pembangunan jiwa (spiritual) harus didahulukan daripada pembangunan badan (fisik), dalam arti pembangunan fisik material tidak akan terlaksana dan terwujud jika para pelaku pembangunan tidak memiliki kematangan spiritual. Karenanya spiritualitas dalam karja menjadi hal yang sangat urgen.

Hamzah Ya'qub (1992) menjelaskan bahwa ada beberapa sikap kematangan spiritual yang perlu diperhatikan dalam menghadapi pekerjaan di antaranya:

1). Niat ihlas. Niat merupakan kemantapan tujuan luhur untuk apa pekerjaan itu dilakukan. Hal ini sesuai dengan falsafah hidup muslim yang bekerja dengan tujuan mengharapkan ridha Allah Swt. Islam memberikan petunjuk pada umatnya, agar dalam setiap aktivitas dunia yang dilaksanakannya tidak boleh keluar dari tujuan taqarrub dan ibadah. 
Walaupun pekerjaan itu formalnya duniawi, tetapi hakekatnya bernilai ibadah jika disertai niat yang ihlas karena Allah Swt. Dengan demikian ihlas merupakan energi batin yang akan membentengi diri seseorang dari segala bentuk perbuatan kotor dalam bekerja, seperti korupsi, mencuri, berbohong, menipu, dan lainnya, karena itu termasuk jalan haram yang amat dibenci oleh Allah Swt.(Toto Tasmara:2004).

2). Kemauan Keras ('azam). Untuk mengembangkan usaha apapun bentuknya, agar dapat maju dan sukses maka diperlukan kemauan keras, tekat membaja. Hal ini merupakan bahan bakar yang dapat menggerakkan seseorang berbuat dan bertindak. Karya besar dimulai dari kemauan keras, tanpa kemauan keras sangat kecil kemungkinan untuk maju dan sukses. Tidak ada keberhasilan kecuali dengan usaha yang sungguh-sungguh walaupun terkadang menyakitkan. Jadi kemauan keras ('azam) harus selalu menghiasi sikap hidup para pekerja atau usahawan muslim. Apabila sudah ber'azam maka kebulatan tekat tentang berhasil dan tidaknya diserahkan sepenuhnya kepada Allah, inilah arti tawakkal yang sebenarnya.

3). Ketekunan (istiqamah). Istiqamah adalah daya tahan mental dan kesetiaan melakukan sesuatu yang telah direncanakan sampai ke batas akhir suatu pekerjaan. Istiqamah juga berarti tidak mudah berbelok arah betapapun kuatnya godaan untuk mengubah pendiriannya, ia tetap pada niat semula. Walaupun dihadapkan dengan segala rintangan, ia masih tetap berdiri (konsisten), ia tetap menapaki jalan yang lurus, tetap tangguh menghadapi badai, tetap berjalan sampai batas, tetap berlayar sampai ke pulau, walaupun sejuta halangan menghadang. Ini bukan idialisme, tetapi sebuah karakter yang melekat pada jiwa seorang muslim yang memiliki semangat tauhid yang tangguh. (Toto Tasmara: 2004).

4). Kesabaran. Kesabaran adalah sikap hidup seorang muslim yang sangat berharga. Sikap ini sangat dibutuhkan dalam berjuang dan bekerja, dan ini termasuk akhlakul karimah yang seharusnya diperjuangkan dalam hidup. Berbagai hambatan dan tantangan akan dapat ditanggulangi selama 
kesabaran masih melekat dan bersemi dalam jiwa manusia. Ahli hikmah mengatakan bahwa kesabaran itu pahit laksana jadam, tetapi buahnya manis bagaikan madu. Kenyataan hidup mengatakan bahwa orang-orang yang sukses dan berhasil mencapai kemajuan dalam hidup karena mereka memiliki kesabaran dalam mengatasi berbagai ujian dan cobaan dalam kehidupan.(Hamzah Ya'qub: 1992).

Keempat sikap hidup yang menunjukkan kematangan spiritual seseorang tersebut, seharusnya dijadikan motor penggerak kehidupan seorang muslim dalam menghadapi pekerjaan, sehingga akan memperoleh hasil secara maksimal dalam arti sukses dalam kehidupan duniawi maupun ukhrawinya. Hal inilah yang seharusnya diimplementasikan dalam kehidupan seorang Muslim.

Islam bukanlah agama langit, melainkan sekaligus agama yang dapat membumi (workable). Penghargaan Islam terhadap budaya kerja bukan sekedar pajangan alegoris, penghias retorika, pemanis bahan pidato, indah dalam pernyataan, tetapi kosong dalam kenyataan. Bekerja yang didasarkan pada prinsip-prinsip iman, bukan saja menunjukkan seorang muslim, melainkan sekaligus meninggikan martabat dirinya sebagai hamba Allah ( 'abdullah). Maksudnya, hanya di tangan hamba Allah yang beriman, apapun yang dilakukan tidak mungkin cacat atau rusak, sehingga pantaslah jika mereka diberi amanah, karena mereka sudah membuktikan dirinya sebagai orang yang dapat dipercaya (al-amin, credible). Ini artinya, hanya orang Islam yang tangguh imannya, yang dapat menjadi pekerja keras dan beretos kerja tinggi.

Iman bukanlah sekedar percaya, iman bukanlah pernyataan yang tersembunyi tanpa bukti, melainkan merupakan pelita jiwa yang menerangi seluruh pori-pori syaraf batin yang mendorong seseorang untuk berbuat menggapai prestasi kerja dalam mengemban misi kehidupannya. Iman akan bermakna bila berwujud dalam gerak kerja keras, ada dorongan untuk membuahkan sesuatu yang bermanfaat.( Toto Tasmara:2004). Dengan kata lain dapat dipahami bahwa tidaklah beriman atau tidaklah sempurna iman 
seseorang yang hanya menyakini dalam hati dan mengucap dalam kata, tetapi hampa dalam perbuatan. Pandai membuat pernyataan, tetapi bodoh mewujudkannya dalam kenyataan.

Berdasarkan sejumlah riwayat, kehidupan Rasulullah, para sahabat dan banyak dari kalangan ulama salaf, ternyata mereka layak dijadikan suri tauladan, tidak hanya di bidang ibadah, melainkan di bidang aktivitas duniawipun mereka menunjukkan memiliki etos kerja tinggi. Dalam kehidupan Rasulullah sendiri, jika dicermati beliau selalu berusaha memanfaatkan waktu untuk melakukan kerja dan perbuatan mulia, baik berupa ibadah mahdah, menuanaikan kewajiban untuk dirinya sendiri dan keluarga, berbuat baik kepada sesama, mengatur dan melaksanakan jihad, dakwah dan lainya. Jadi Rasulullah sendiri adalah seorang figur yang memiliki etos kerja amat tinggi.

Para sahabat terdahulu (khulafaur Rasyidin) juga banyak yang mempunyai sikap kerja yang mencerminkan etos kerja tinggi dan sangat mengagumkan, seperti Abu Bakar, sebelum menjadi khalifah beliau adalah pedagang yang setiap hari pergi ke pasar melakukan jual-beli. Bahkan sampai beberapa waktu setelah diangkat menjadi khalifah pekerjaan itu masih dijalani. Khalifah berikutnya, Umar bin al-Khattab, selain termashur amat sederhana dan jujur, sejarah mencatatnya sebagai pemimpin yang suka bekerja keras dan penuh tanggung jawab. Demikian juga Usman ibn Affan, ia merupakan sosok hartawan murah hati, pengusaha besar yang sukses dan ia mempunyai sifat teliti, tekun, rajin dan pekerja keras. Dan khalifah terakhir, Ali bin Abi Talib, ia dikenal sebagai pemimin yang jauh dari sifat malas, dan merupakan khalifah yang sangat giat dalam mengurusi kepentingan ummat. Ia amat menghargai waktu dan senatiasa mengabadikan waktunya untuk melakukan amal kebajikan.( Asifuddin, ). Jadi hasil kerja keras, berupa harta benda yang diperoleh para sahabat selama bekerja bukan untuk membangun rumah mewah atau berfoya-foya, melainkan untuk menolong umatnya yang membutuhkan dan membantu tegaknya syiar dan perjuangan Islam. 
Dalam perjalanan sejarah ulama-ulama terdahulu, seperti Imam Ghazali, Imam Suyuti, Imam Bukhari, Imam Muslim, al-Kindi, Ibn Rusdi, Ibn Khaldun, Fahrurrazi, Ibn Taimiyah, Ibn Qayyum dan sejumlah ulama- lainnya adalah ulama-ulama Islam yang berhasil mengukir sejarah dunia dengan berbagai prestasi yang luar biasa, dan itu semuanya dapat diraihnya bukan dengan sikap malas atau santai, melainkan dicapainya dengan semangat kerja atau etos kerja yang sangat tinggi. ${ }^{1}$ Jadi tujuan mereka bekerja hanyalah untuk memperoleh ridla Allah dan demi kejayaan umat Islam. Mereka bekerja dalam rangka beribadah pada Allah Swt. Karena itu hasil yang diperoleh benar-benar berkah dan bermanfaat baik bagi dirinya maupun umat Islam secara keseluruhan.

Kesemuanya itu menjadi bukti bahwa etos kerja tinggi pada hakikatnya sudah menyatu dalam kehidupan tokoh-tokoh panutan umat Islam, semenjak Nabi Muhammad Saw, sahabat khulafaur rasyidin, ulama-ulama klasik, ulama-ulama modern dan seterusnya diwarisi oleh sejumlah masyarakat Islam di berbagai negeri, termasuk di Indonesia.

Jikalau kemudian ada umat Islam yang beretos kerja rendah, hal itu pasti bukan disebabkan oleh ajaran Islam yang salah, melainkan karena faktor pemahaman manusia terhadap ajaran Islam yang keliru atau sangat dimungkinkan adanya faktor lain di luar ajaran Islam seperti karena orientasi dalam bekerja mereka berubah, yakni tidak lagi sesuai dengan konsep Islam, maka yang terjadi adalah kehancuran. Hal ini terbukti dalam sejarah, yakni ketika umat Islam silau oleh dunia dan lupa akan akhirat, tujuannya bukan untuk mengharap ridla Allah melainkan untuk mendapatkan harta sebanyakbanyaknya, menumpuk-numpuk kekayaan dan bersenang-senang, maka akhirnya umat Islam jatuh ke lembah kemunduran dan menjadi umat yang termarjinalkan oleh situasi dan kondisi jaman, yang pada akhirnya tidak memiliki sesuatu yang berarti dan patut dibanggakan.

\section{DAFTAR PUSTAKA}


Abdul Aziz El-Qussy, (1974), Pokok-pokok Kesehatan Mental, ter. Zakiah Darajat, Jakarta Bulan Bintang.

Arif Budiman, (1984), Ilmu Sosial di Indonesia, Perlunya Pendekatan Struktural, Jakarta: PLP2M.

Anwar Prabu Mangkunegara, (2007), Mangemen Sumber Daya Manusia Perusahan, Bandung: Remaja Rosda Karya.

Bukhari Zaini, (1991), Managemen Sumber Daya Manusia, Jakarta: Ghalia Indonesia.

Gliffort Greertz, (1974), The Interpretation of Culture, New York: Basic Book.

Harun Nasution, (1996), Islam Rasional, Gagasan dan Pemikiran, Bandung: Mizan.

Hadari Nawawi, (2001), Managemen Sumber Daya Manusia untuk Bisnis yang Kompetitif, Yogyakarta: Gajah Mada University Press.

Imam Muhammad Abu Zahrah, (1996), Aliran Politik dan Aqidah dalam Islam, Jakarta: Logos Publishing House.

Musa Asy'arie, (1997), Islam, Etos Kerja dan Pemberdayaan Ekonomi Umat, Yogyakarta: Lesfi.

Max Weber, (2000), Etika Protestan dan Semangat Kapitalisme, ter. Yusup Priosudiarjo, Surabaya: Pustaka Promethea.

Nurcholis Madjid, (1995), Islam Doktrin dan Peradaban, Jakarta: Yayasan Wakaf Paramadina.

Pandji Anoraga, (1992), Psikologi Kerja, Jakarta: Rineka Cipta.

Robert N. Bellah, (2000), Beyond Beleif, Esai-esai tentang Agama di Dunia Modern, Jakarta: Paramadina.

Taufik Abdullah, (1982), Agama, Etos Kerja dan Perkembangan Ekonomi, Jakarta: LP3ES.

Toto Tasmara, (1995), Etos Kerja Pribadi Muslim, Yogyakarta: Dana Bhakti Wakaf.

-------------, Membudayakan Etos Kerja Islami, Jakarta: Gema Insani. Yusuf Qordhawi, (1996), Karakteristik Islam, Surabaya: Risalah Gusti. 